\title{
Early diagnosis of bacterial infection in patients with septicopyemia by laboratory analysis of PCT, CRP and IL-6
}

\author{
LIQIN GAO $^{1 *}$, XINGHUI LIU $^{2 *}$, DENGHAI ZHANG $^{2}$, FENGXIA XU $^{2}$, QING CHEN $^{2}$, YE HONG $^{2}$, \\ GANG FENG $^{3}$, QIN SHI $^{4}$, BIN YANG ${ }^{1}$ and LIMIN XU ${ }^{2}$ \\ ${ }^{1}$ Department of Laboratory Medicine, The First Affiliated Hospital of Fujian Medical University, Fuzhou, Fujian 350004; \\ Departments of ${ }^{2}$ Clinical Laboratory, ${ }^{3}$ Intensive Care Unit and ${ }^{4}$ Emergency, Shanghai Gongli Hospital, \\ The Second Military Medical University, Shanghai 200135, P.R. China
}

Received September 6, 2016; Accepted March 29, 2017

DOI: $10.3892 / \mathrm{etm} .2017 .4417$

\begin{abstract}
The aim of the present study was to investigate the early diagnostic values of measuring procalcitonin (PCT), C-reactive protein (CRP), and interleukin-6 (lL-6) levels in patients with bacterial infections and septicopyemia. Ninety-two patients with septicopyemia who were diagnosed and treated in the First Affiliated Hospital of Fujian Medical University between December 2012 and October 2013 were randomly selected. Based on results of hemoculture, the patients were divided into the Gram-negative bacterial infection group $(n=47)$ and the Gram-positive bacterial infection group $(n=45)$. Immune nephelometry was used for measuring serum CRP levels, electrochemiluminescence assay was used to measure serum PCT and IL-6. The levels of serum CRP, PCT, and IL-6 in the Gram-negative bacterial infection group were significantly higher than in the Gram-positive group. Analysis with Spearman's correlation coefficient showed that there were positive correlations between the levels of PCT and CRP, and between PCT and IL-6 $(\mathrm{P}<0.05)$. The diagnosis of Gram-negative bacterial infections was as follows: The area under the PCT curve was $0.974(\mathrm{P}<0.05)$ with sensitivity and specificity of 96.8 and $93.5 \%$, respectively. The area under the CRP curve was $0.953(\mathrm{P}<0.05)$ with sensitivity and specificity of 94.2 and $91.7 \%$, respectively. The area under the IL-6 curve was $0.925(\mathrm{P}<0.05)$ with sensitivity and specificity of
\end{abstract}

Correspondence to: Dr Bin Yang, Department of Laboratory Medicine, The First Affiliated Hospital of Fujian Medical University, 20 Chazhong Road, Fuzhou, Fujian 350004, P.R. China

E-mail: yn2z63@163.com

Dr Limin Xu, Department of Clinical Laboratory, Shanghai Gongli Hospital, The Second Military Medical University, 129 Miaopu Road, Shanghai 200135, P.R. China

E-mail: xr8i51@163.com

${ }^{*}$ Contributed equally

Key words: procalcitonin, C-reactive protein, interleukin-6, septicopyemia, bacterial infection
93.6 and $90.5 \%$, respectively. The diagnosis of Gram-negative bacterial infections was as follows: The area under the PCT curve was $0.854(\mathrm{P}<0.05)$ with sensitivity and specificity of 92.7 and $91.8 \%$, respectively. The area under the CRP curve was $0.832(\mathrm{P}<0.05)$ with sensitivity and specificity of 90.2 and $89.3 \%$, respectively. The area under the IL- 6 curve was 0.817 $(\mathrm{P}<0.05)$ with sensitivity and specificity of 89.4 and $81.5 \%$, respectively. In conclusion, PCT, CRP, and $1 \mathrm{~L}-6$ can act as early diagnostic markers for bacterial infections in patients with septicopyemia.

\section{Introduction}

Sepsis is a general inflammatory reaction syndrome caused by infections from various organisms such as fungi, parasites, bacteria, and viruses (1). The onset may be accompanied by hypoperfusion of tissues and organs, and symptoms such as oliguria, lactic acidosis, disturbance of consciousness, and septic shock. The rate of mortality from sepsis ranges from 25 to $40 \%$ of patients in the ICU (2). The global morbidity from sepsis is increasing annually and a large number of patients die from its complications (3). In recent years, the use of antibiotics has controlled the total mortality but antibiotic abuse, such as excessive use, long-term use, and non-semeiological use, has become severe safety problem (4). The rate of antibiotic use among Chinese inpatients is $\sim 56 \%$ and is sometimes as high as $90 \%$, while it is $25 \%$ in developed countries in Europe and America (5). In actuality, the number of patients who truly require the use of antibiotics is $<20 \%$ in our country and the excessive rate of use represents abuse. At present, imageological examinations and clinical manifestations cannot act as effective diagnostic bases of infection for clinicians. Although blood bacteria culture is relatively effective, it takes a long time. Additionally, antibiotic abuse leads to difficulty of early diagnosis and makes identification of the types of bacterial infection (Gram-positive or Gram-negative) more difficult (6). However, the combined measurement of procalcitonin (PCT), C-reactive protein (CRP), and interleukin-6 (1L-6) can increase the sensitivity and specificity of diagnosis of early bacterial infections. This study provides a basis for classification of bacterial infections in patients with septicopyemia by PCT, CRP, and lL-6. 
Table I. General parameters of patients.

\begin{tabular}{lcccc}
\hline Parameters & $\begin{array}{c}\text { Gram-negative bacterial } \\
\text { infection group }(\mathrm{n}=47)\end{array}$ & $\begin{array}{c}\text { Gram-positive bacterial } \\
\text { infection group }(\mathrm{n}=45)\end{array}$ & $\mathrm{t} / \chi^{2}$ & P-value \\
\hline Sex (male/female) & $26 / 21$ & $27 / 18$ & 0.206 & 0.650 \\
Age (years) & $40-78$ & $40-76$ & & \\
Mean age (years) & $53.36 \pm 7.89$ & $54.85 \pm 8.18$ & 0.889 & 0.376 \\
ICU stay (days) & $9.16 \pm 2.35$ & $8.78 \pm 2.47$ & 0.756 & 0.451 \\
Total cholesterol (mmol/l) & $5.73 \pm 0.84$ & $5.82 \pm 0.85$ & 0.511 & 0.611 \\
Triglyceride (mmol/l) & $2.76 \pm 1.02$ & $2.84 \pm 0.83$ & 0.412 & 0.681 \\
FiO2/O2 (mmHg) & $153.34 \pm 8.83$ & $152.75 \pm 7.15$ & 0.351 & 0.726 \\
Total leucocyte count $\left(\mathrm{x} 10^{9} / \mathrm{l}\right)$ & $8.73 \pm 3.64$ & $9.83 \pm 3.75$ & 1.428 & 0.156 \\
APACHE II score & $16.43 \pm 2.83$ & $15.87 \pm 2.64$ & 0.980 & 0.329 \\
\hline
\end{tabular}

\section{Patients and methods}

Patients. The present retrospective study was performed on 92 patients with septicopyemia who were randomly selected from the First Affiliated Hospital of Fujian Medical University between December 2012 and October 2013. Criteria of septicopyemia must accord to at least 2 of the following conditions (7): i) Low fever (body temperature, $<36.0^{\circ} \mathrm{C}$ ); ii) fever (body temperature, $>38.3^{\circ} \mathrm{C}$ ); iii) anhelation (frequency, $>30$ times/min); iv) heart rate is two standard deviations higher than the normal range corresponding to age or $>90$ times/min; v) altered consciousness; vi) positive fluid balance $(>20 \mathrm{ml} / \mathrm{kg}$ and lasted for over $24 \mathrm{~h}$ ) or obvious edema; and vii) blood glucose $>110 \mathrm{mg} / \mathrm{dl}$ or $7.7 \mathrm{mmol} / \mathrm{l}$ without history of diabetes. The criteria for septicopyemia were as follows: i) Leukocyte count $>12 \times 10^{9} / 1$; ii) leukocyte count $<4.0 \times 10^{9} / 1$; iii) normal leukocyte count with over $10 \%$ immature leukocytes; vi) PCT is two standard deviations higher than normal value; and v) serum CRP is two standard deviations higher than normal value. After blood culture, patients were divided into the Gram-negative bacterial infection group $(n=47)$ and the Gram-positive bacterial infection group $(n=45)$ according to pathogenic bacteria. The general parameters of patients are shown in Table I. This study was approved by the Ethics Committee of the First Affiliated Hospital of Fujian Medical University. Signed written informed consents were obtained from all participants before the study.

Instruments and reagents. Instruments included a DEM-3 scientific plate washer (Beijing Tuopu Analytical Instrument Co., Ltd., Beijing, China), a Bio-Rad Model 680 microplate reader (Bio-Rad Laboratories, Inc., Hercules, CA, USA), an E601 electrochemistry luminescence analyzer (Roche Diagnostics, Basel, Switzerland), a BN-II specific protein apparatus (Siemens AG, Munich, Germany), and a UniCel DxI 800 immunoassay (Beckman Coulter, Inc., Brea, CA, USA). Reagents included a PCT kit (Roche Diagnostics), IL-6 kit (Beckman Coulter, Inc.), and CRP kit (Siemens AG).

Sample collection. A total of $5 \mathrm{ml}$ fasting blood was collected in the morning from patients in both groups and centrifuged at 2,500 $\mathrm{x}$ g for $15 \mathrm{~min}$ within $30 \mathrm{~min}$ of being collected. The upper layer of serum $(1.5 \mathrm{ml})$ was transferred to centrifuge tubes, labeled, and stored at $-70^{\circ} \mathrm{C}$.
Detection of CRP. Immune nephelometry was used to measure the levels of CRP according to the instructions of the CRP kit. Samples were agglutinated with polystyrene particles with covered surfaces with anti-CRP monoclonal antibody. A protein analyzer was used to measure values and the concentrations of CRP in samples were determined with reference to a standard curve prepared from diluents of known concentration.

Detection of PCT. Electrochemiluminescence (ECL) was used to measure the levels of PCT according to the instructions of the PCT kit and the results were auto-determined with an automatic electrochemical luminescence immunity analyzer. i) Incubation: Samples (30 $\mu$ l), biotin-labeled PCT antibody, and ruthenium-labeled PCT antibody were mixed and incubated to form a sandwich-like antigen-antibody immune complex; ii) re-incubation: Streptavidin-coated particles were added and allowed to incubate to combine with the previous complex and immunomagnetic beads. iii) Chemiluminescence: Inhalational reaction solutions were measured and the particles were adsorbed on an electrode surface with electromagnetic interaction. Data were measured with a photomultiplier and the concentrations were automatically calculated with a calibration curve.

Detection of IL-6. A chemiluminescence immunoassay using magnetic microparticles was used to measure the levels of IL-6 according to the instructions of the IL-6 kit. i) Incubation: Samples were added to the instrumental inspection holes for incubation in combination with blocking agents, mouse monoclonal IL-6 antibody, and alkaline phosphatase-coated particles; ii) adsorption and flushing: Particles were adsorbed on an electrode surface with electromagnetic interaction and those that did not adhere were cleared away; and iii) luminescence: Chemiluminescence was added to the reaction tubes to perform the measurement with illuminance. Concentrations were calculated using Two-Point collection calibration curves.

Statistical analysis. SPSS 19.0 software (IBM, Armonk, NY, USA) was used for data analysis and the levels of CRP, PCT, and IL- 6 are presented as mean \pm standard deviation (mean $\pm \mathrm{SD}$ ). A t-test was used to detect the correlation with CRP, PCT, and IL-6 as well as with the Spearman's rank correlation coefficient. ROC curve analysis was performed on 
Table II. Comparison of CRP, PCT, and IL-6 in the two groups.

\begin{tabular}{lcccc}
\hline Groups & No. of cases & PCT (ng/ml) & CRP (mg/l) & IL-6 (ng/l) \\
\hline Gram-negative bacterial infection & 47 & $7.28 \pm 3.25$ & $69.38 \pm 15.18$ & $162.23 \pm 33.63$ \\
Gram-positive bacterial infection & 45 & $3.84 \pm 2.48$ & $56.43 \pm 14.42$ & $143.75 \pm 32.82$ \\
t-test & & 5.689 & 4.192 & 2.666 \\
P-value & & 0.0001 & 0.0001 & 0.0091 \\
\hline
\end{tabular}

PCT, procalcitonin; CRP, C-reactive protein; IL-6, interleukin-6.

Table III. Correlation of CRP, PCT, and IL-6 in the two groups.

\begin{tabular}{lccc}
\hline & $\begin{array}{c}\text { Correlation coefficient } \\
\text { in the Gram-negative } \\
\text { bacterial infection group }\end{array}$ & P-value & $\begin{array}{c}\text { Correlation coefficient } \\
\text { in the Gram-positive } \\
\text { bacterial infection group }\end{array}$ \\
\hline CRP level & 0.943 & 0.006 & 0.778 \\
IL-6 level & 0.647 & 0.024 & 0.699 \\
\hline
\end{tabular}

PCT, procalcitonin; CRP, C-reactive protein; IL-6, interleukin-6.

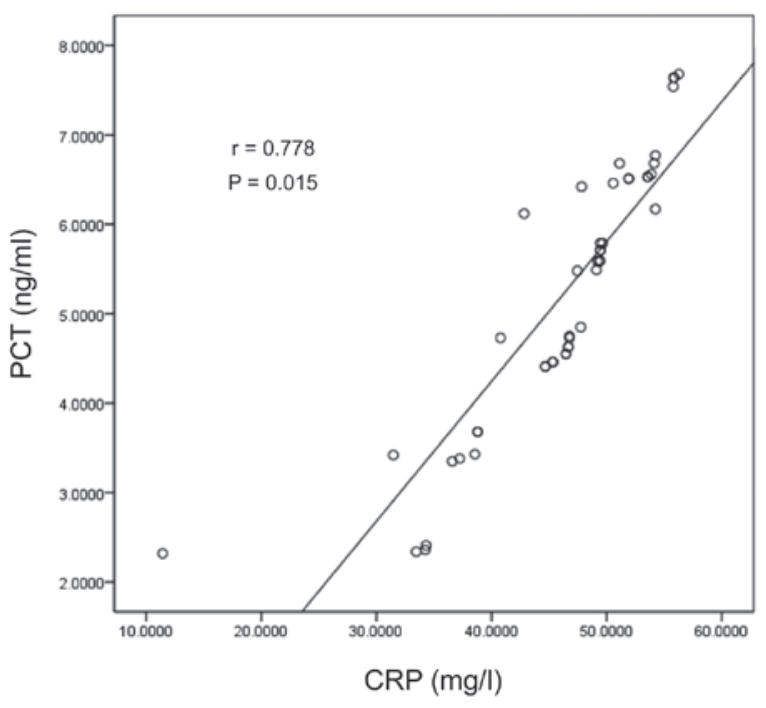

Figure 1. Scatter diagram of PCT and CRP in the Gram-positive bacterial infection group. PCT, procalcitonin; CRP, C-reactive protein.

CRP, PCT, and IL-6 levels as diagnostic standards. $\mathrm{P}<0.05$ was considered statistically significant.

\section{Results}

Comparison of CRP, PCT, and IL- 6 in the two groups. The levels of CRP, PCT, and IL-6 in the Gram-negative bacterial infection group were higher than those in the Gram-positive bacterial infection group, and the differences were statistically significant $(\mathrm{P}<0.05)$ (Table II).

Correlation analysis of CRP, PCT, and IL- 6 in the two groups. Analysis with the Spearman's rank correlation coefficient was used, suggesting the levels of PCT were positively correlated

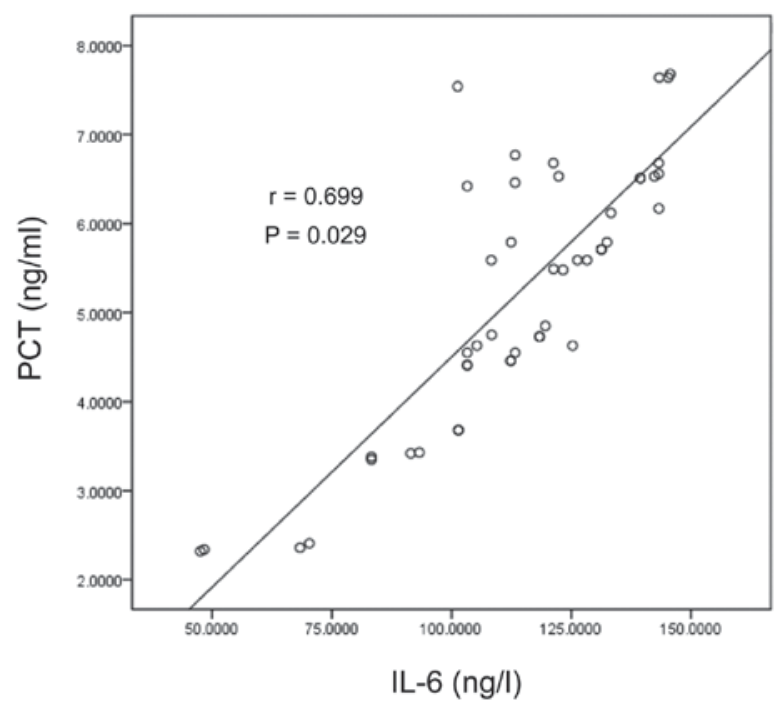

Figure 2. Scatter diagram of PCT and IL-6 in the Gram-positive bacterial infection group. PCT, procalcitonin; IL-6, interleukin-6.

with CRP and IL-6 in the Gram-negative bacterial infection group $(\mathrm{r}=0.532,0.416, \mathrm{P}<0.05)$ and in the Gram-positive bacterial infection group $(\mathrm{r}=0.478,0.316, \mathrm{P}<0.05)$ (Table III and Figs. 1-4).

Diagnosis of patients with Gram-negative bacterial infection. The area under the PCT curve was $0.974(\mathrm{P}<0.05)$ with sensitivity and specificity of 96.8 and $93.5 \%$, respectively, when the critical value was $8.35 \mathrm{ng} / \mathrm{ml}$. The area under the CRP curve was $0.953(\mathrm{P}<0.05)$ with sensitivity and specificity of 94.2 and $91.7 \%$, respectively, when the critical value was $74.65 \mathrm{mg} / \mathrm{ml}$. The area under the IL-6 curve was $0.925(\mathrm{P}<0.05)$ with sensitivity and specificity of 93.6 and $90.5 \%$, respectively, when the critical value was $171.65 \mathrm{ng} / \mathrm{ml}$ (Fig. 5). 


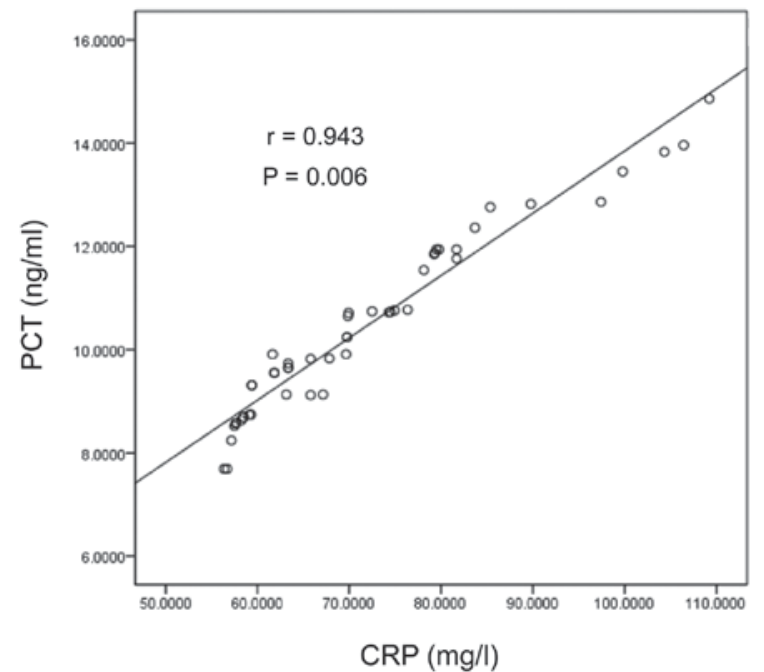

Figure 3. Scatter diagram of PCT and CRP in the Gram-negative bacterial infection group. PCT, procalcitonin; CRP, C-reactive protein.

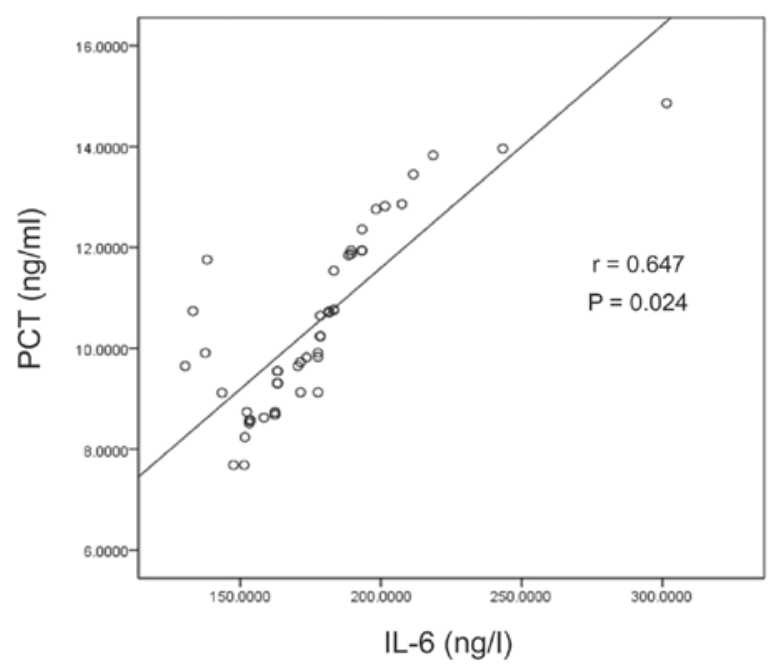

Figure 4. Scatter diagram of PCT and IL-6 in the Gram-negative bacterial infection group. PCT, procalcitonin; IL-6, interleukin-6.

Diagnosis of patients with Gram-positive bacterial infection. The area under the PCT curve was $0.854(\mathrm{P}<0.05)$ with sensitivity and the specificity of 92.7 and $91.8 \%$, respectively, when the critical value was $4.35 \mathrm{ng} / \mathrm{ml}$. The area under the CRP curve was $0.832(\mathrm{P}<0.05)$ with sensitivity and specificity of 90.2 and $89.3 \%$, respectively, when the critical value was $60.65 \mathrm{mg} / \mathrm{ml}$. The area under the IL-6 curve was $0.817(\mathrm{P}<0.05)$ with sensitivity and specificity of 89.4 and $81.5 \%$, respectively, when the critical value was $150.65 \mathrm{ng} / \mathrm{ml}$ (Fig. 6).

\section{Discussion}

Lack of timely diagnosis and control of initial infections, combined with drug-resistance from antibiotic abuse, destroys the normal flora of septic patients, which leads to disorder of the flora in the body. Therefore, infections that persist can be fatal $(8,9)$. Sepsis is sometimes caused by common infections which makes the body at immunosuppression phase, thus results in multi-organ dysfunction. Hence, hospital infections

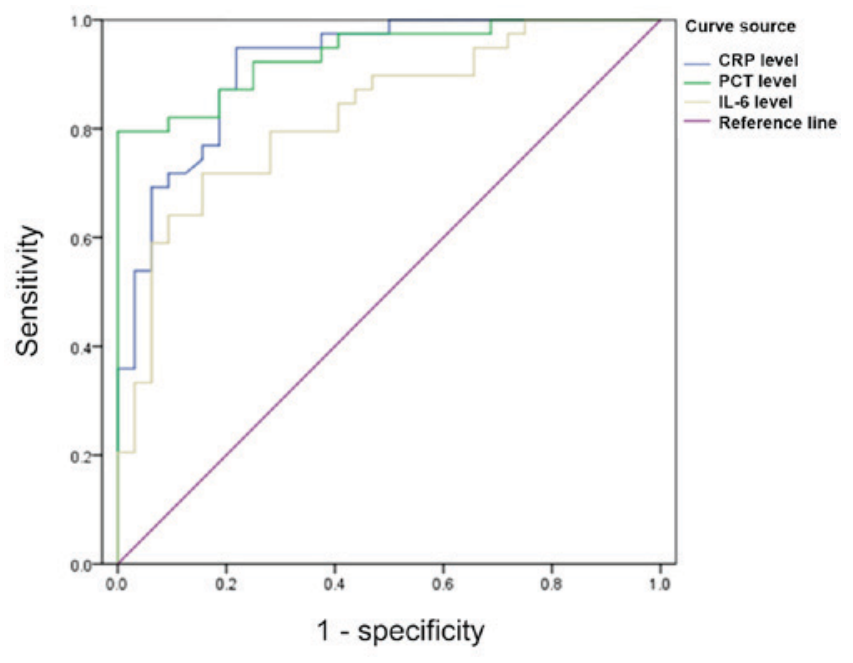

Figure 5. ROC curves of PCT, CRP and IL-6 for diagnosis of Gram-negative bacterial infection. PCT, procalcitonin; CRP, C-reactive protein; IL-6, interleukin-6.

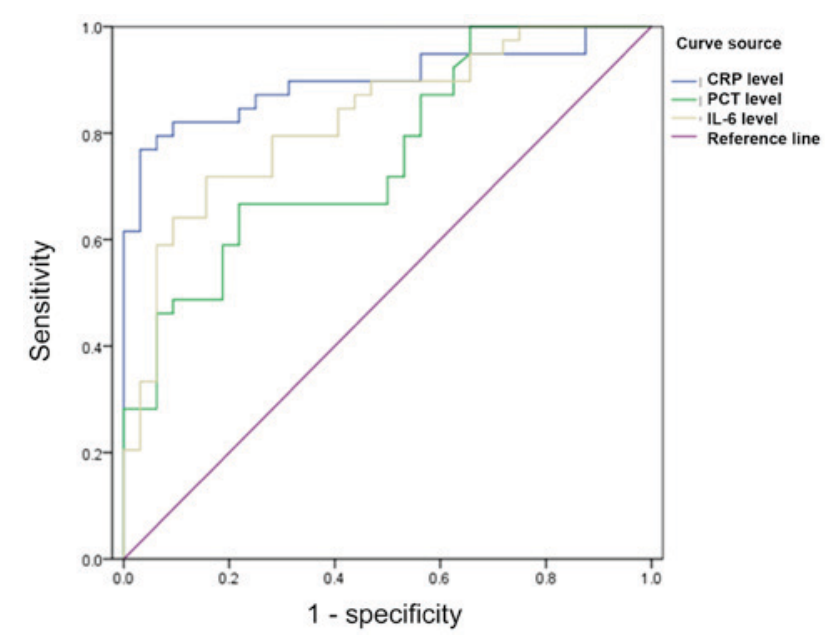

Figure 6. ROC curves of PCT, CRP and IL-6 for diagnosis of Gram-positive bacterial infection. PCT, procalcitonin; CRP, C-reactive protein; IL-6, interleukin-6.

and their susceptibility occur more easily (10). Common pathogenic Gram-negative bacteria cause septicopyemia, such as Escherichia coli, which is the most common cause. In recent years, the morbidity from septicopyemia caused by Gram-positive bacteria has increased, especially from Staphylococcus aureus infection (11). Therefore, early diagnosis of bacterial infections in patients with septicopyemia is of great significance.

Significance of PCT in septicopyemia. PCT is an inflammatory factor without hormonal activity with relative molecular weight of $13,000 \mathrm{kDa}$ and half-life of $\sim 24 \mathrm{~h}$. Several studies have suggested that PCT is the most useful biomarker for diagnosis of septicopyemia, with precedence over other laboratory indicators (12). PCT levels are very low in healthy subjects, and are almost undetectable $(<0.0025 \mathrm{Ug} / \mathrm{ml})(13)$. Under severe injury and infection, the body releases multiple inflammatory cytokines which leads to secondary injury in tissues and organs. Patients with septicopyemia continuously releases 
PCT, inducing the systemic inflammation response syndrome. Correlational studies suggested that PCT can be detected within $2 \mathrm{~h}$ after general bacterial infection, shows a rapid increase within $6 \mathrm{~h}$, then reaches a peak value around $24 \mathrm{~h}$. Therefore, it provides a basis for early diagnosis and warning of septicopyemia $(14,15)$. In this study, elevated levels of PCT in the Gram-negative bacterial infection group were markedly higher than in the Gram-positive group. From analysis of ROC curves in both groups with septicopyemia, PCT can act as a predictive index of Gram-negative bacterial infection when the threshold value is $8.35 \mathrm{ng} / \mathrm{ml}$, and of Gram-positive bacterial infection when the threshold value is $4.35 \mathrm{ng} / \mathrm{ml}$.

Application of CRP detection in septicopyemia. CRP is an acute phase reactive protein that was identified in the 1930s, the levels of which are lower than $1 \mathrm{mg} / \mathrm{l}$ in plasma of healthy subjects (16). Injury, bacterial infection, and septicopyemia cause the levels of CRP to increase (17). In this study, the measured CRP levels were higher than normal in both the Gram-positive and Gram-negative bacterial infection groups. The levels in the Gram-positive group were significantly higher than in the Gram-negative group. Correlational studies revealed that CRP levels reach peak values from 48 to $72 \mathrm{~h}$ after bacterial infection, and the values can increase by several hundred-fold compared with normal values, and act as a marker of septicopyemia (18). In this study, through analysis of the ROC curves of different bacterial infections, it was found that CRP can serve as a predictive index of Gram-negative bacterial infections when its threshold value is $74.65 \mathrm{mg} / \mathrm{l}$ and of Gram-positive bacterial infections when its threshold value is $60.65 \mathrm{mg} / \mathrm{l}$. In addition, with the advantages of simple and effective detection, and sustainable dynamic monitoring, it is of great significance for avoiding missed diagnosis in patients with early-stage septicopyemia and providing guidance for appropriate control.

Application of IL-6 detection in septicopyemia. IL-6 is an acute phase lymphocyte factor. It is an important member of the IL family with bidirectional function of mobilizing the defensive reaction and inhibiting immune dysfunction (19). Normal IL-6 levels are very low, but increase abnormally with the presence of septicopyemia and with the severity of infection. When different bacterial infections occur, mononuclear macrophages are activated and a large amount of IL-6 is secreted which causes damage to organs via blood circulation. Persistent infection leads to a rapid increase of IL-6 (20). In this study, IL-6 levels in the Gram-negative bacterial infection group were significantly higher than in the Gram-positive group. Through analysis of the ROC curves of different bacterial infections, the results showed that IL- 6 can serve as a predictive index of Gram-negative bacterial infections when its threshold value is $171.65 \mathrm{ng} / \mathrm{l}$ and for Gram-positive bacterial infections when the threshold value is $150.65 \mathrm{ng} / \mathrm{l}$. Compared with the levels of PCT and CRP, the area under the curve was relatively smaller.

In conclusion, combined laboratory measurements of PCT, CRT, and 1L-6 can not only provide early diagnosis for patients with sepsis and other bacterial infections, but can enhance the sensitivity and specificity on the estimation of classification of infection, which is of great prognostic value.

\section{Acknowledgements}

The present study was supported by the Key Discipline Construction Project of Pudong Health Bureau of Shanghai (no. PWZx2014-03) and Shanghai Health and Family Planning Commission Project (no. 20134396).

\section{References}

1. National Heart, Lung, and Blood Institute ARDS Clinical Trials Network; Truwit JD, Bernard GR, Steingrub J, Matthay MA, Liu KD, Albertson TE, Brower RG, Shanholtz C, Rock P, Douglas IS, et al: Rosuvastatin for sepsis-associated acute respiratory distress syndrome. N Engl J Med 370: 2191-2200, 2014.

2. Du B, An Y, Kang Y, Yu X, Zhao M, Ma X, Ai Y, Xu Y, Wang Y, Qian C, et al; China Critical Care Clinical Trial Group: Characteristics of critically ill patients in ICUs in mainland China. Crit Care Med 41: 84-92, 2013.

3. Shahait M, Degheili J, El-Merhi F, Tamim H and Nasr R: Incidence of sepsis following transrectal ultrasound guided prostate biopsy at a tertiary-care medical center in Lebanon. Int Braz J Urol 42: 60-68, 2016.

4. Viswanathan VK: Off-label abuse of antibiotics by bacteria. Gut Microbes 5: 3-4, 2014

5. The Alliance for Prudent Use of Antibiotics (APUA): The cost of antibiotic resistance to US families and the health care system. APUA, Boston, 2014.

6. Ristescu I and Grigoraş I: Biomarkers in early diagnosis of sepsis. Jurnalul De Chir 8: 131-14, 2012 (In Romanian).

7. Holder AL, Gupta N, Lulaj E, Furgiuele M, Hidalgo I, Jones MP, Jolly T, Gennis P and Birnbaum A: Predictors of early progression to severe sepsis or shock among emergency department patients with nonsevere sepsis. Int J Emerg Med 9: 10, 2016.

8. Klein Klouwenberg PM, Cremer OL, van Vught LA, Ong DS, Frencken JF, Schultz MJ, Bonten MJ and van der Poll T: Likelihood of infection in patients with presumed sepsis at the time of intensive care unit admission: a cohort study. Crit Care 19: 319, 2015.

9. Hughes D and Karlén A: Discovery and preclinical development of new antibiotics. Ups J Med Sci 119: 162-169, 2014.

10. Marwick CA, Guthrie B, Pringle JE, McLeod SR, Evans JM and Davey PG: Identifying which septic patients have increased mortality risk using severity scores: a cohort study. BMC Anesthesiol 14: 1-9, 2014.

11. Ramachandran G: Gram-positive and gram-negative bacterial toxins in sepsis: a brief review. Virulence 5: 213-218, 2014.

12. Davies J: Procalcitonin. J Clin Pathol 68: 675-679, 2015.

13. Bréchot N, Hékimian G, Chastre J and Luyt CE: Procalcitonin to guide antibiotic therapy in the ICU. Int J Antimicrob Agents 46 (Suppl 1): S19-S24, 2015.

14. Tan BH, Png ME, Yeo CP and Wong GC: Procalcitonin in febrile neutropenia - timing is important. Support Care Cancer 22: 583-584, 2014

15. Bodmann KF, Schenker M, Heinlein W and Wilke $M H$ : Procalcitonin as a tool for the assessment of successful therapy of severe sepsis: an analysis using clinical routine data. Med Klin Intensivmed Notfmed: Jul 4, 2016 (In German) (Epub ahead of print).

16. Gelalis ID, Arnaoutoglou CM, Politis AN, Batzaleksis NA, Katonis PG and Xenakis TA: Bacterial wound contamination during simple and complex spinal procedures. A prospective clinical study. Spine J 11: 1042-1048, 2011.

17. Nishiofuku H, Tanaka T, Marugami N, Sho M, Akahori T, Nakajima $Y$ and Kichikawa K: Increased tumour ADC value during chemotherapy predicts improved survival in unresectable pancreatic cancer. Eur Radiol 26: 1835-1842, 2016.

18. Christensen MB, Eriksen T and Kjelgaard-Hansen M: C-reactive protein: quantitative marker of surgical trauma and post-surgical complications in dogs: a systematic review. Acta Vet Scand 57: 71, 2015.

19. Pedersen BK and Febbraio M: Exercise and interleukin-6 action. Expert Rev Endocrinol Metab 319-321: 2014, 2014.

20. Rosser EC, Oleinika K, Tonon S, Doyle R, Bosma A, Carter NA, Harris KA, Jones SA, Klein N and Mauri C: Regulatory B cells are induced by gut microbiota-driven interleukin-1 $\beta$ and interleukin-6 production. Nat Med 20: 1334-1339, 2014. 